\title{
Managing Differences as Internationalization Strategy; A Case of Daiso Japan Entry to Indonesia
}

\author{
Inke Maria \& Vinsensio Dugis \\ Universitas Airlangga
}

\begin{abstract}
It has been widely accepted that multinational corporations (MNCs) have been part of important agencies playing critical role in determining global governance. Increasing globalization, featuring in various forms, have critically facilitated the operation of MNCs globally and increasing influence of MNCs on global politics. However, differences that could come in the forms of culture, politics, geography, and economy, are still crucial obstacles for MNCs competing internationally. Therefore, building and employing a spot-on international strategy becomes a crucial issue. Taking-up a Daiso Japan entry to Indonesia as a case study, this article higlights how cultural adaptation could become a key success for an MNC. Equally, it reveals how far culture is needed by Daiso Japan when doing its international expansion into Indonesia. The case informed that some cultural elements such as language, customs, and manners can be instrumental elements supporting the success of employing cultural adaptation as an international strategy. These cultural elements are potential sources for adjusting with local culture through aggregation process.
\end{abstract}

Keywords: adaptation, cultural aggregation, cultural differences, internationalization strategy.

Telah dipahami secara luas bahwa korporasi multinasional (MNC) telah menjadi bagian penting agensi global yang memainkan peran krusial menentukan tatakelola global. Globalisasi yang semakin meningkat dan mewujud dalam berbagi bentuk telah memfasilitasi beroperasinya korporasi secara global serta peningkatan pengaruhnya terhadap politik global. Namun demikian, perbedaan yang dapat mewujud dalam bentuk kebudayaan, politik, geografi, dan ekonomi tetap menjadi hambatan berat bagi korporasi yang beroperasi secara global. Karena itu, membangun dan mengaplikasi strategi internasional yang sesuai dan tepat-guna menjadi isu penting. Mengambil kasus kesuksesan pola masuk Daiso Japan ke Indonesia, artikel ini memperlihatkan bagaimana adaptasi kebudayaan dapat menjadi kunci sukses bagi sebuah korporasi multinasional. Artikel ini menguak seberapa jauh aspek kebudayaan dibutuhkan oleh Daiso Japan ketika melakukan ekspansi ke Indonesia. Kasus ini memperlihatkan bahwa sejumlah elemen kebudayaan seperti bahasa, kebiasaan, dan caracara yang santun dapat menjadi elemen instrumental yang mendukung kesuksesan dalam mengimplemntasikan adaptasi kebudayaan sebagai strategi internasional. Elemen-elemen budaya ini berfungsi sebagai sumber-sumber potensial bagi langkah-langkah penyesuaian dengan budaya lokal melalui proses agregasi.

Kata Kunci: adaptasi, agregasi budaya, perbedaan budaya, strategi internasional. 


\section{Introduction}

When a multinational corporations (MNC) plans to expanding globally, cultural differences always come into consideration. Multinational firms whose operations are borderless have to consider the cultural variability of different regions of the world and develop cultural understanding (Moran \& Moran 2004). These differences could range from local attitudes, taste preferences, language, religion, management style, gender discrimination, skills, personalities, and education to mention a few. To be successful, firms need to not only concentrating on the financial aspects of strategy but should also mold their business actions in accordance with the local cultural models (Morosini 1998). Undeniably, cultural differences can be one of the main challenging factors in the internationalization of any MNC.

Daiso Sangyo Corp. (hereafter Daiso) is a Japanese retail firm headed by Hirotake Yano with headquartered in Higashihiroshima, Hiroshima Prefecture. It was founded in 1977 and originally started its business in the domestic level adopting a single-price model; all items 100 yen. It then slowly expands its business not just domestically in Japan but also globally outside Japan. By March 2015 Daiso has 2,900 stores in Japan and 1,400 overseas spreading over 26 countries. The first overseas store was opened in Taiwan in 2001, while in Indonesia it started opening its retail shop in 2004 (Daiso Globala 2016). What is the secret behind Daiso's success in today's demanding business environment? It operates with three values, 'Quality', 'Variety', and 'Uniqueness', considered as Daiso's pillars in retail business (Daiso Globalb 2016).

Daiso has started its operation in Indonesia since 2004 marked by the opening of its first shop, Daiso Artha Gading, in Jakarta and then gradually adds the number of its shops. In 2005, the second shop was opened in Blok M Plaza in Jakarta, followed a year latter by its third shop (Daiso Darmo) and fourth shop (Daiso Margorejo) consecutively, both in Surabaya. Furthermore, in 2007, two more shops began to operate, Daiso Paris Van Java in Bandung and Daiso Tunjungan Plaza in Surabaya. Therefore, in five years after it first operation in Indonesia, Daiso has managed to open six shops in three big cities namely Jakarta, Surabaya, and Bandung. The numbers have been steady until 2012 when Daiso began to further add more shops starting with Daiso Kasablanka, Jakarta, and then a year after, Daiso Baywalk and Daiso Sudirman both in Jakarta. Two more shops were opened, Daiso 1 Park Jakarta in 2014 and Daiso Kemang in Jakarta in 2015 (Daiso 2016). Until 2016, Daiso Japan has managed to add more branches in Pakuwon Trade Center Surabaya, so that there are now 13 stores in total operated in Indonesia (Daiso Japan on Twitter 2016). In managing its operation in Indonesia, Daiso collaborates with local company, PT. Just Shop Jaya and until now Daiso Indonesia moves under the banner of that company (Ananda in Bisnis Tempo Online 2012).

The increasing number of Daiso retail shops in Indonesia indicates that it has gained success and Indonesian customers have welcomed its presence. What cultural adaptation strategy has Daiso adopted when entering Indonesian market? How has it overcome cultural obstacles in Indonesia? In the rest of the article, it is argued that in overcoming the obstacles of cultural differences, Daiso has fittingly managed it by 
implementing an adaptation strategy combined with aggregation on culture. Daiso sells products that go well with the needs of many Indonesians and able to making necessary adjustments by such as using Indonesian language on the instructions of the name of goods and greetings to customers.

The research for this article focused on a strategy of cultural adaptation taken by Daiso in facing cultural constrain so that it can grow and accepted in Indonesia. The authors specifically observed Daiso shops in Surabaya, where data both collected directly and indirectly. Direct data collection was taken through field research, conducted through in-depth unstructured-open interviews. Equally, to find out whether the shopping experience at Daiso Indonesia is the same as Daiso in Japan, the authors conducted interviews with two shopers from Indonesia and Japan (Mrs Laily Sukmawati and Mrs Morimoto Asuka), both are loyal consumers of Daiso and have shopped both in Japan and Indonesia. In addition, the authors also conducted an interview to one of the shop employees at Daiso Surabaya branch. Field research was carried out at three Daiso branches in Surabaya; Tunjungan Plaza, Papaya Darmo, and Pakuwon Trade Center. In addition, the secondary data were explored and collected by literature studies from books, research reports, newspapers, journals, internet resources, and other written documents. The findings on how Daiso has played its adaptation strategy combined with aggregation on culture will be presented in this article, which will be divided into three main sections; the internationalization model initially used by Daiso Japan in its global expansion, cultural differences faced by Daiso when entering Indonesia, and the strategies used to overcome these cultural differences.

\section{Internationalization Model}

Theoretically, there are two patterns or model possibly opted by the firm before entering foreign market, namely rapid internationalization model and incremental internationalization (Wach 2015). The first refers to the process that tends to grow fast in the early stages of its development (Freeman \& Schroder 2012), which in most cases is adopted by new lines of business deciding to go international (McDougall et al. 2003), where they avoid incremental internationalization pattern (McDougall et al. 1994). In contrast, incremental internationalization model refers to an expanding process that develops step-by-step, preferring to domestically stronger first before venturing at global market. The activities of the company in the domestic market are taken gradually in order to establish a solid business so that it can be well known first in the home country. This is taken partly as a preparation stage to expand the company's branch to other countries (Li \& Dalgic 2004). The incremental internationalization model suggests that the firm internationalized by applying the simplest to the most complex stages or in other words involving a gradual process of internationalization (Johanson \& Vahlne 2002).

Daiso initially build a solid foundation in the domestic level before it is actually ready to entering global market. Since its inception as a 100 yen retail company, Daiso has continued to develop its potential in the domestic markets. Formed in 1977 under the 
name of Daiso Sangyo Inc., it started its business by setting up initial sales office in Tokyo in 1980, the following year in Kyushu. It has opened thousands of its shops in big cities around Japan and in 1983 was able to raise capital by 50 million yen. Since then, Daiso's capital has continued to increasing, reaching 2.7 billion yen by 2001 (Daiso Globalb 2016). Daiso develops itself domestically for almost 25 years before actually expanding wings into foreign markets since 2001. By March 2015, Daiso has 2,900 stores in Japan and 1,400 overseas, spreading over 26 countries. It is a fact therefore that Daiso has built a strong and solid base in domestic market before it eventually began to entering global markets. Thus, the internationalization model used by Daiso is a combination of rapid and incremental internationalization.

It is important to also jot down that Daiso is one among many of Japanese 100 yen store (almost similar and equal to $\$ 1$ dollar store), making Japan well known for 100 yen shop culture. The following are other well known 100 yen stores in Japan; Seria, CanDo, Watts, Tokutoku Ya, 100 Yen House Lemon, World Kikaku, Hyakuemon, FLET'S, Lawson Store 100, Daikoku. Out of these stores, the big three are Daiso, Seria, and CanDo with their combine total stores in city of Tokyo alone are 412 where Daiso has 200 stores, Seria has 52 stores, and CanDo has 160 stores. While in entire Japan Daiso has over 3,00o stores, Seria has 1,323, and CanDo has 967 (Ono 2017). Given the fact that Daiso has expanded operation globally, it has been recognized being the most successful 100 yen store. It has successfully gained domestic as well as international reputation. The following graph shows the rising amount of Daiso's sales that has grown hand-in-hand with the increasing number of Daiso's shops.

\section{Graph 1- Daiso's Increasing Sales and Shops}

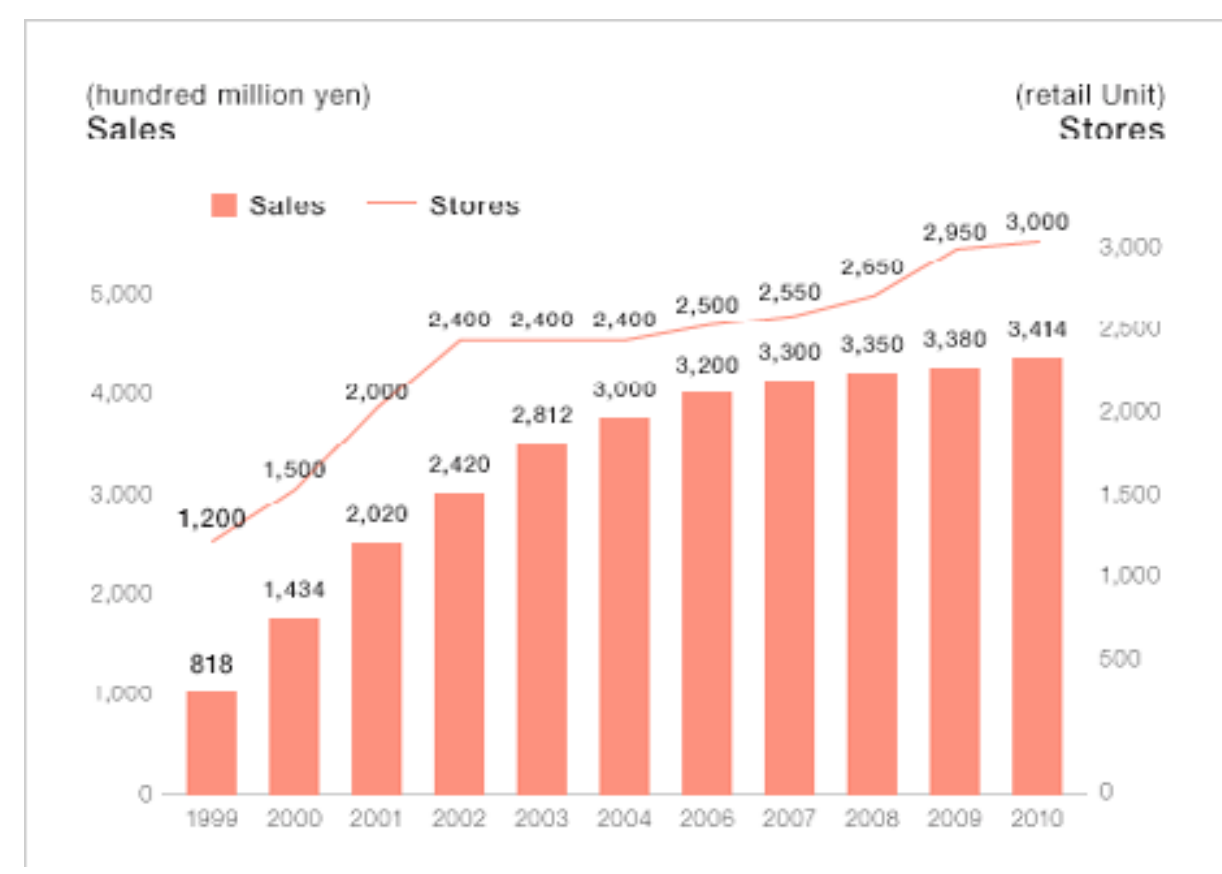

(Source: Daiso Global, 2016) 


\section{Managing Differences as Internationalization Strategy;}

A Case of Daiso Japan Entry to Indonesia

\section{Cultural Differences}

In terms of cultural attributes, there are obviously many elements that can differentiate between attributes reffering to Japanese culture and Indonesian culture. There are three noted attributes that seems to be considered critical when entering Indonesian market, namely language, customs, and manners. Language can be clearly seen from the packaging of goods, instructions on the name of the goods, and daily Japanese greetings used by store clerks in welcoming buyers. Goods are packaged in away that allow the customers able to know what the good is simply from seeing the form of that particular good. Illustration of photos on figure 1 and figure 2 below clearly explains it. In figure 1 , the customers know exactly that it is a tripod because they can see in the packaging that it is a tripod. Similarly, in figure 2 the customers know that 'shokki' means cutlery and drinkware simply by figuring out that the instructions is placed above the goods. All these are aimed to easily facilitate Indonesian customers. Furthermore, daily Japanese greetings used by store clerks in welcoming customers or buyers are aimed at giving Japanese cultural flavor to the customers.

\section{Figure 1 - Picture of a Tripod}

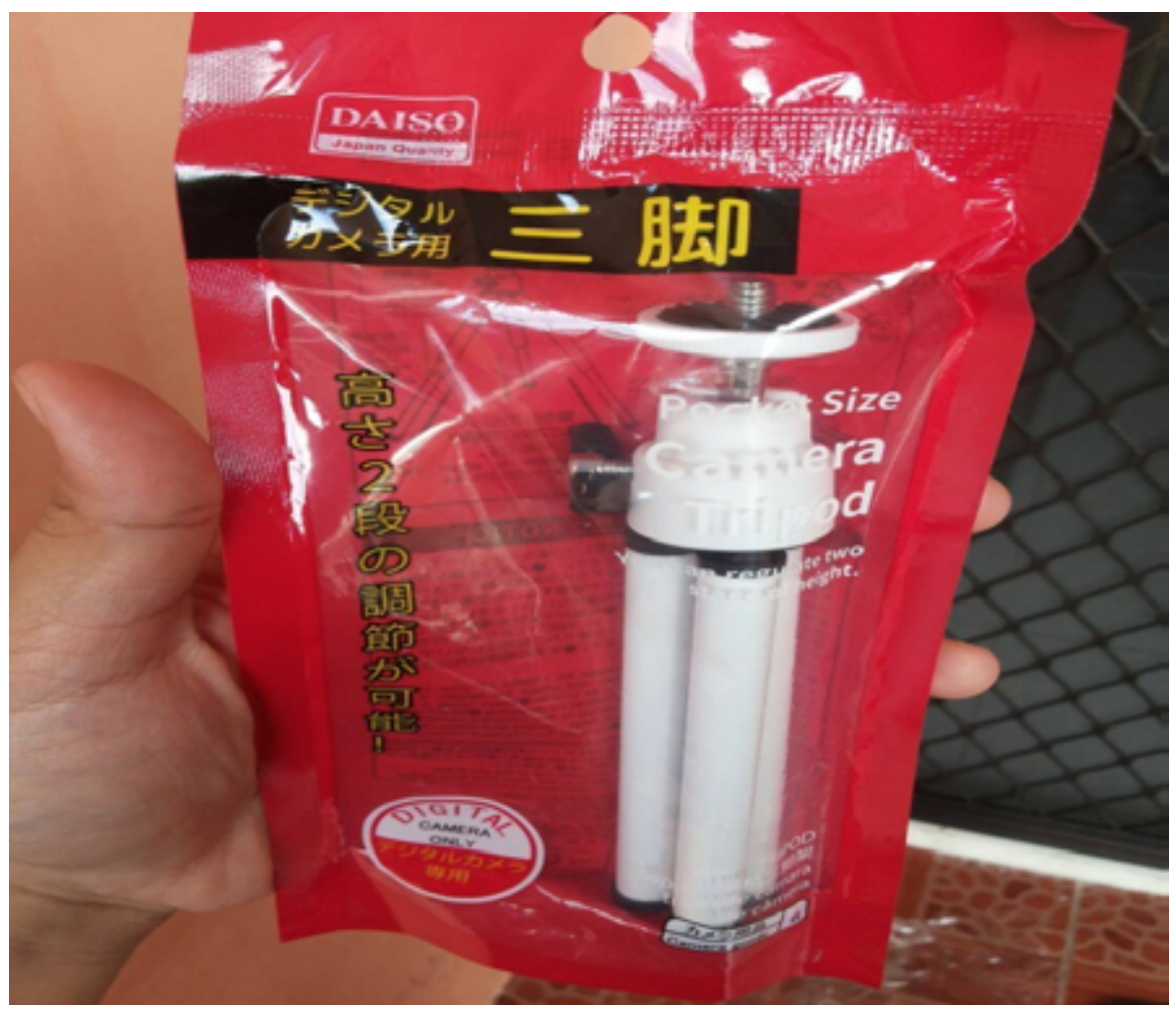

(Source: Photo taken at Daiso Mall Kota Kasablanka Jakarta, 6 September 2015) 
Figure 2 - 'Shokki' Meaning Cutlery \& Drinkware

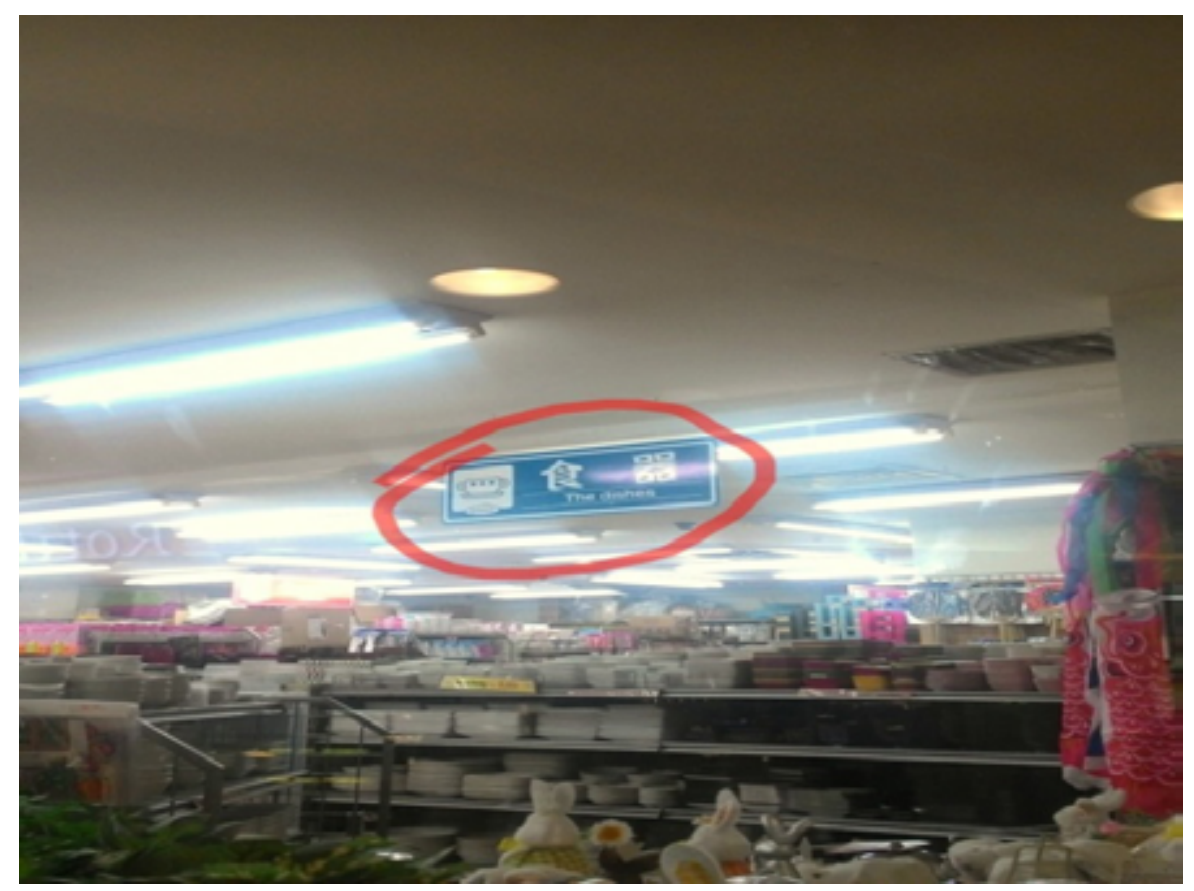

(Source: Photo taken at Daiso Tunjungan Plaza Mall Surabaya, 20 December 2016)

Furthermore, the customs and manners practiced in Daiso are forms of aisatsu or greetings (Matsura 1994). These particular greetings are used in order to build a feeling of affectionate, friendly, and respectful in everyday life (Nihongo Kyouiku Gakkai 1997). A lot of aisatsu is used in various situations in a daily life in Japan, for example when meeting people in the morning saying ohayou gozaimasu (good morning), when going to bed say oyasuminasai (good night or can be spoken in the office when fellow employees will leave home), while attending a wedding and saying kekkon omedetou gozaimasu (congratulations on his marriage) to the bride.

The first form of these greetings is the word irasshaimase, meaning welcome and it is often used by shopkeepers to greet the visitors. The irasshaimase pronunciation is also a form of the shopkeeper's hospitality towards visitors (Bahasa Jepang 2017). This form of aisatsu is also often used when a shopkeeper welcomes consumers coming to the shop, and often the shopkeepers 'greet it loudly' for the sake of attracting visitors passing in front of the store. The remark is as follows: "Irasshaimase ... irasshaimase ... Please Daiso its all 25,00o".

The next form of aisatsu is otsukaresamadeshita, a form of expression used to appreciate one's work. This phrase is often used by superiors to subordinates or co-workers (Megumi, 2001). In Japanese companies, this particular expression is commonly used while in Daiso Indonesia it is also applied to familiarize the existing culture in Japan. As a greeing, otsukaresamadeshita is often expressed by store clerks when they are changing working-shift from the morning group to the afternoon ones. When the store clerk with the afternoon shift comes rolling into a special room of 
employees, they say otsukaresamadeshita to the employees who have finished shift and will go home.

The last greeting is arigatou gozaimasu, usually delivered by the cashier to the customer of Daiso who has finished shopping and made payment transactions. Arigatou gozaimasu means expressing gratitude both to the creator or other people (Megumi, 2001). It is also important to add that these greetings are usually expressed with bending the body that signifies respect for the other person. Culture of bend the body was never separated from the habits of the Japanese when doing aisatsu or even on regular talking. Bending the body in Japanese is called ojigi, which means a necessity that is done on any occasion, and has been taught from childhood. Ojigi apparently is also practiced when the cashier staff finished serving consumers who have been shopping. Usually they say arigatou gozaimasu first and followed by bending the body that signifies gratitude and respect to consumers who have been to Daiso.

In practice, there are 5 different types of ojigi based on the level of decency; noding or bending 5 degrees usually to friends or close family, bending 15 degrees (eshaku) slightly more formal usually to people who already know at the office, bend respect 30 degrees (keirei) very formal to a boss or an older person. Bending high respect 45 degrees (sai-keirei) has a very deep meaning, done when feeling guilty or respectful to the emperor, and bowing to kneeling is usually done to beg for forgiveness because of a fatal mistake. Following are examples of ojigi shape:

\section{Figure 3 - Form of Ojigi by Male and Female}

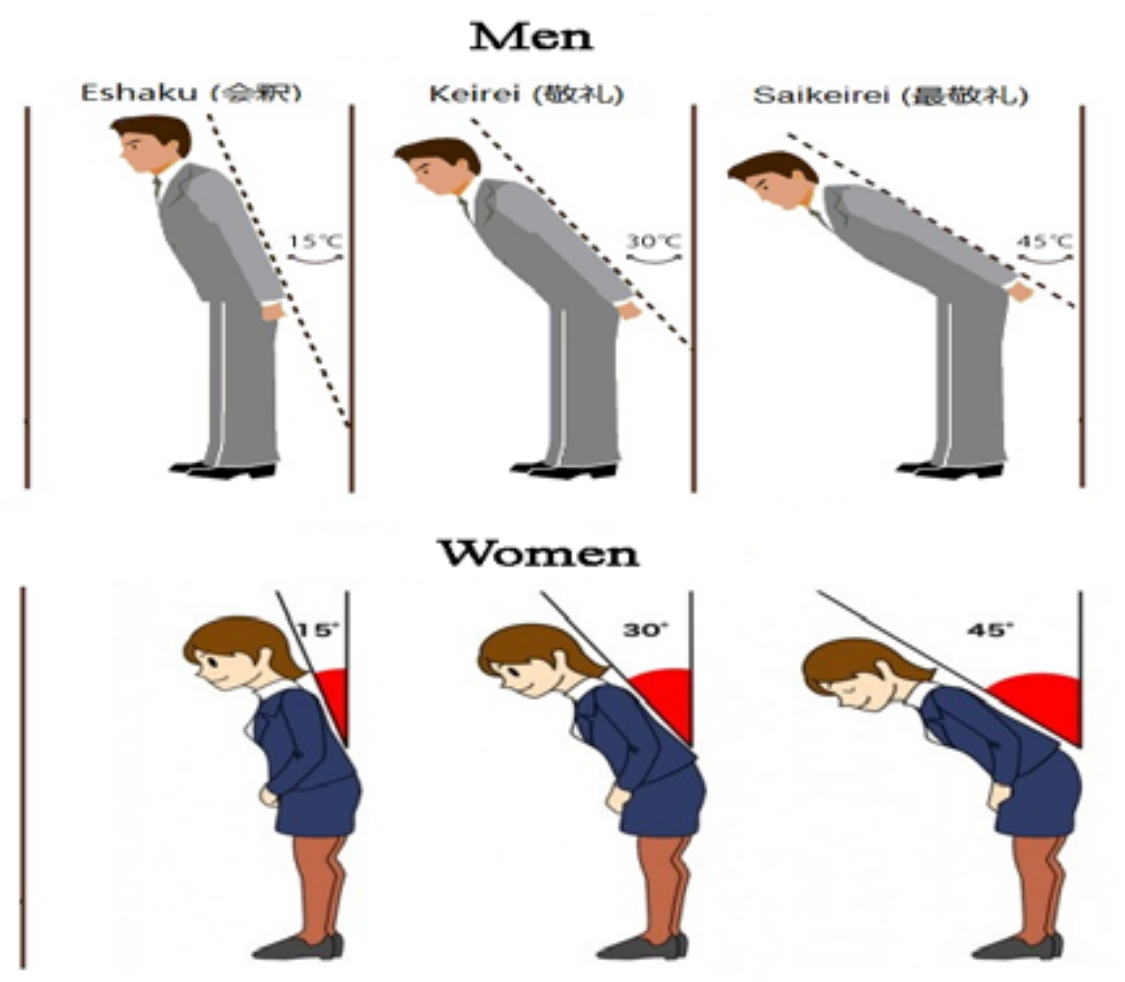

(Source: Jepang.net 2017) 


\section{Strategies Used to Overcone Differences}

In order to overcome cultural differences, Daiso uses a combination of adaptation and aggregation strategy on culture. The aggregation strategy is not only about geographical approach, but there are also non-geographical approaches, namely cage approach (cultural, administrative, geographic, and economic). From an interview with one of Daiso Tunjungan Plaza clerk (interview was conducted on 16 March 2016), is informed that Daiso begins with conducting training for shopkeepers for 3 months with the aim to understand the vision and mission of the company and the concept of one price owned by Daiso Japan. In addition, because Daiso is a Japanese company, Daiso in Indonesia recruits employees who are all Indonesian, making consumers believe that all their products are from Japan, as well as to facilitate consumers when making purchases. Consumers who ask for goods can be easily assisted by shopkeepers, as all of them are Indonesians.

The visible cultural aggregation is on the elements of language, customs and manners. The use of a word or sentence is closely related to a person's habit when using it in daily life. The first difference noted when we visit a Daiso shop is the shopkeeper attracting visitors with greetings "irasshaimase..irasshaimase .. please come to Daiso, all are 25 thousand rupiah". They are standing in front of the store while shouting the greetings above, as it is ilustrated in the figure below.

\section{Figure 4 - Daiso Shopkeepers at Tunjungan Plaza Surabaya}

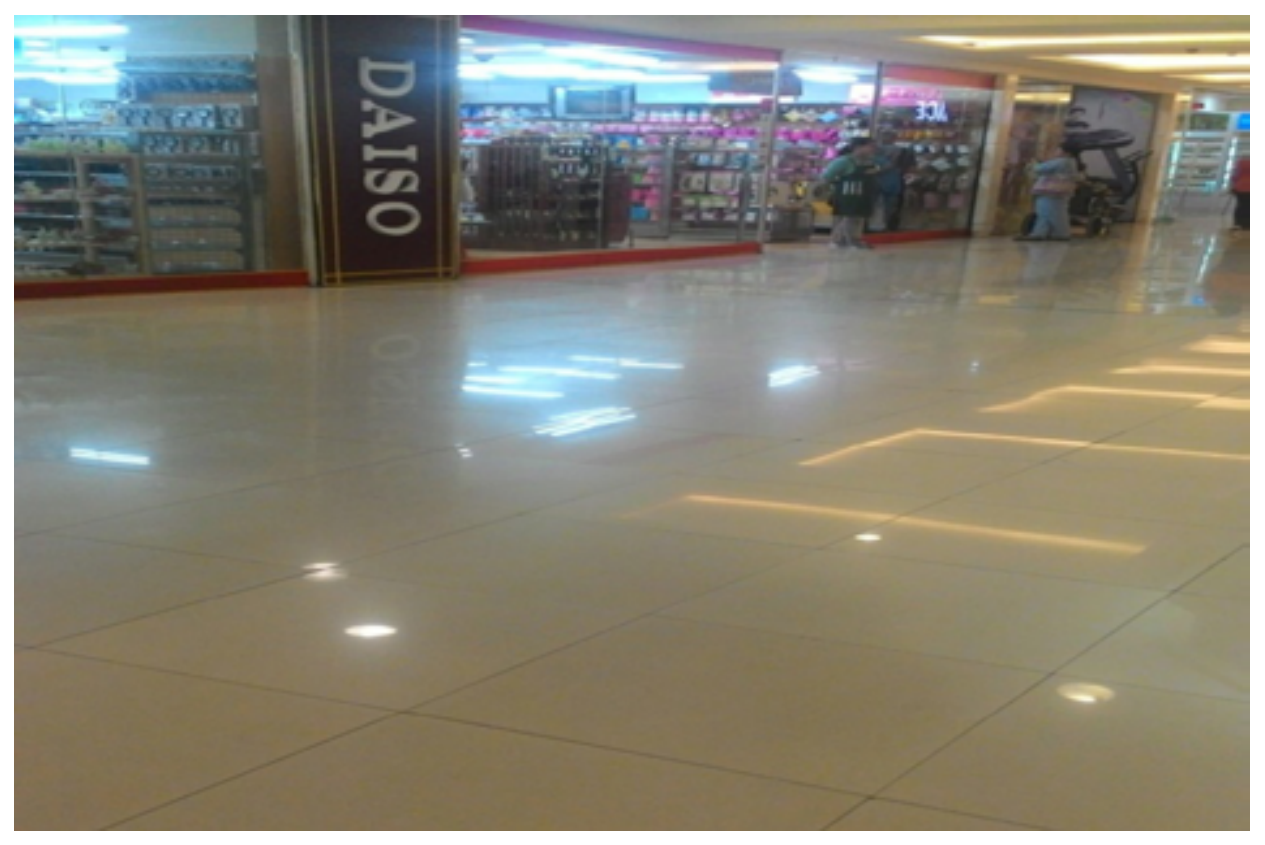

(Source: Photo taken on 20 Desember 2016)

Greeting of irasshaimase indeed belongs to one of Japanese culture when shopkeepers greet their customers. It is then used by Daiso making visitors interested and 
immediately knowing that Daiso is originally from Japan. Though for Indonesians this might sound to be noisy, but for the Japanese it is a common thing taken in many stores in Japan. To make even sure that the greeting has become a habit, the author watched one Japanese television station, Waku Waku Japan, which one of the shows (Quiz Surprise!! Japan) covered the crowd in Harajuku, including Daiso in that location. And true to the author's thinking, that in Daiso Harajuku also use these words to welcome customers who come.bAnother importat greetings word is otsukaresamadeshita that is spoken to honor the hard work of others. Its is practiced in Daiso Indonesia with the aim of honoring employees who have finished working. Daiso teaches employees to respect each other's performance. That is one of Daiso's strategies to cultivate employees for mutual respect and friendliness to fellow workers. Such customs and manners are not common in Indonesia, especially in shops. Last is arigatou gozaimasu (thanks) followed by ojigi (respectful position with bowing / head). This strategy is applied to all Daiso, both in Japan and Indonesia. The goal is not only to thank, but to cultivate a sense of gratitude for the visits of customers who have been shopping at Daiso. A thank you followed by bowing, a goal to honor customers who have taken the time to stop by and shop at Daiso. For Daiso the essence of gratitude is not only from words alone, but also must be shown by gestures that really show a form of gratitude. The practices of these customs and manners by Daiso in Indonesia is one way of maintaining the characteristic, that by being a company from Japan which greatly appreciates and serve consumers well.

In the discussion with several shopkeepers, language is also one of cultural attributes that plays an important role. Based on field research in Surabaya, it was faound that in Daiso Tunjungan Plaza, instructions using Japanese and Englisg is still used, while in Daiso Darmo and Pakuwon Trade Centre, the instructions of the name of the goods are all using the Indonesian language. This way is done so that consumers who are looking for and choosing goods to buy is not confused with its usefulness, although the packaging is still the same using Japanese and English. It is clear therefore that the strategy used to deal with cultural differences in Daiso Japan in Indonesia is a combination of adaptation with aggregation to culture. The strategy was accomplished by overcoming Daiso's more emphasis on the introduction of Japanese culture through the everyday greeting used in store, and all of it well practiced by Daiso Japan employees in Indonesia. The following figure is an example where name of goods have been using Indonesian language. 
Figure 5 - Goods at Daiso Pakuwon Trade Center \& Papaya Darmo
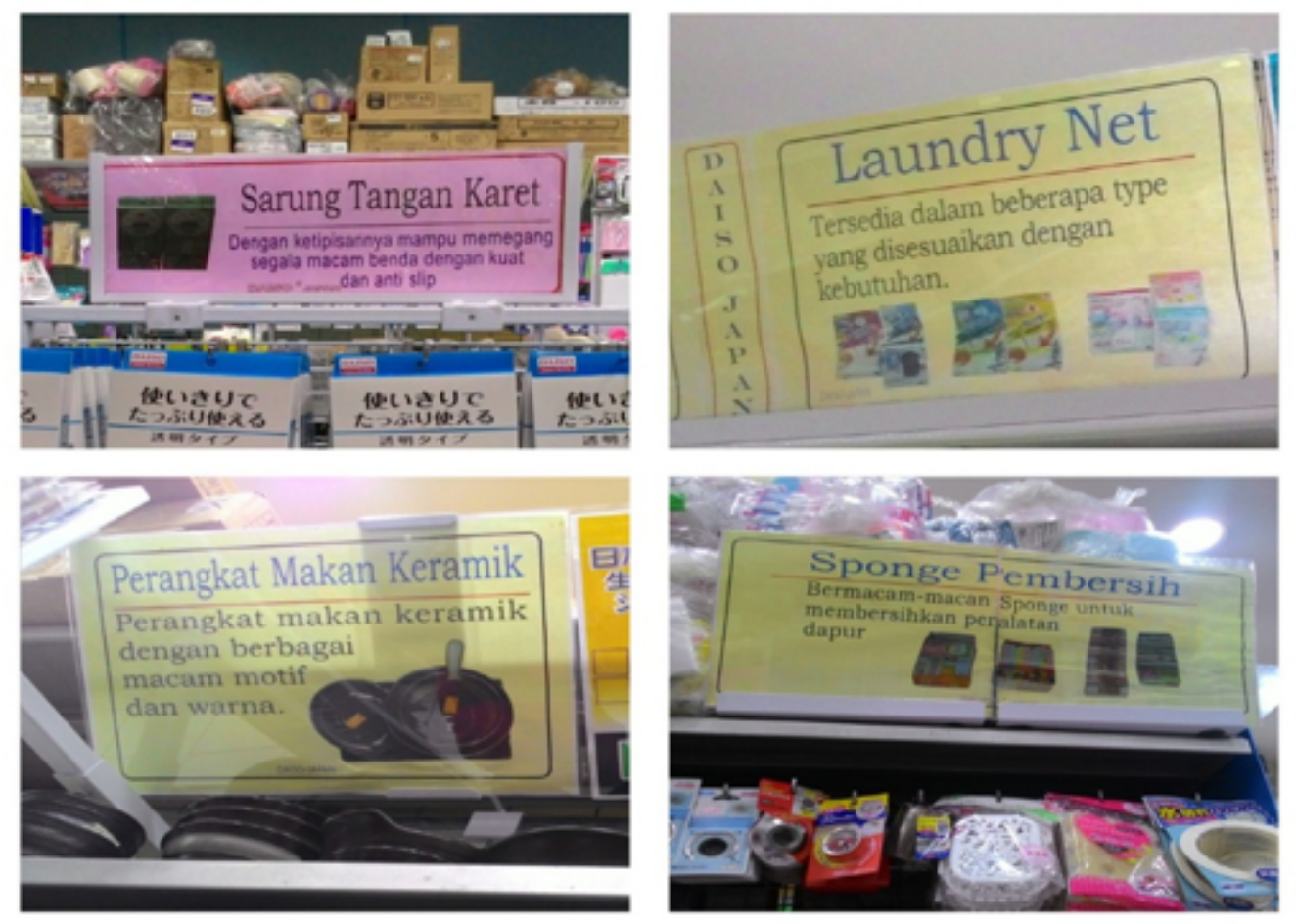

(Source: Photo taken on 23 December 2016)

\section{Conclusion}

Daiso Japan enters countries to expand internationally by using rapid internationalization. The strategy used to overcome cultural differences is to combine adaptation and aggregation against culture. In addition, there are more differences on the Daiso side. The strategy was accomplished by overcoming Daiso's more emphasis on the introduction of Japanese culture through the everyday greeting used in store, and all of it well practiced by Daiso Japan employees in Indonesia, as well as the use of goods name instructions with the Indonesian language. Daiso case in Indonesia informed that some cultural elements such as language, customs, and manners can be instrumental elements supporting the success of employing cultural adaptation as an international strategy. These cultural elements are potential sources for adjusting with local culture through aggregation process, and in the case of Daiso, these elements have successfully supported Daiso's increasing expantion in Indonesia. 


\section{Acknowledgment}

The authors like to appreciate those who have in different ways helped the completion of the research for this paper. This paper is a reworking version from a Master thesis by the first author who was supervised by the second author in the Department of International Relations, Universitas Airlangga Surabaya.

\section{References}

\section{Books and Chapter in Books}

Harris, Philip R., Moran, Robert T. \& Moran, Sarah V. 2004. Managing Cultural Differences, Elsevier.

Matsuura, Kenji. 1994. Kamus Bahasa Jepang-Indonesia. Kyoto; Kyoto Sangyo University Press.

Megumi, Shimada. 2001. わかるビジネス日本語. USA: ASK/Business Network Corporation.

Morosini, Piero. 1998. Managing Cultural Differences: Effective strategy and execution across cultures in global corporate alliance, Pergamon.

Nihongo Kyouiku Gakkai. 1997. 日本語教育辞典. Tokyo: Daishuukanshoten.

\section{Journals \& Online Journals}

Bangara A, et al. 2012. Legitimacy and Accelerated Internationalization: An Indian Perspective, Journal of World Business, 47 (4): 623-634.

Fuyuno, Ichiko \& David Kruger. "King of The Mall”. Far Eastern Economic Review; Aug 30, 2001; 164, 34; ABI/INFORM Collection, Tokyo pg. 34

Johanson, J. \& J.-E. Vahlne. 1977. "The Internationalization Process of the Firm - A Model of Knowledge Development and Increasing Foreign Market Commitments." Journal of International Business Studies, 23-32.

Li, L., et al. 2004. "Internationalization Process of Small and Medium-sized Enterprises: Toward a Hybrid Model of Experiential Learning and Planning”, Management International Review, 44 (1): 93-116.

McDougall, et al. 1994. Explaining the formation of international new ventures: The limits of theories from international business research, Journal of Business Venturing, 9 (6): 469-487.

McDougall P.P, etal. 2003. A Comparison of Internastional and Domestic NewVentures, Journal of International Enterpreneurship, 1 (1): 59-82.

Wach, K. 2015. Incremental versus Rapid Internationalisation of Firms: Results of Exploratory Investigation from Poland. Entrepreneurial Business and Economics 
Review, 3 (4): 37-48. doi: 10.15678/EBER.2015.030403

\section{Online Articles \& Others}

Bahasa Jepang. 2017. “4 Versi Pengucapan Selamat Datang” [online] http://www. bahasajepang.org/2015/04/4-versi-pengucapan-selamat-datang-dalam.html [acessed 10 April 2017].

Daily Japan. 2017. “Tanabata: Festival Bintang Tahunan Saat Musim Panas di Jepang” [online] http://the-dailyjapan.com/tanabata-festival-bintang-tahunan-saatmusim-panas-di-jepang/ [accessed 10 April 2017].

Daiso Globala. 2016. "Business Concept" dalam http://www.daisoglobal.com/about/ concept/ [accessed 14 January 2016].

Daiso Globalb. 2016. "Daiso's History" dalam http://www.daisoglobal.com/about/ history/ [accessed 9 October 2016].

Daiso Japan on Twitter. 2016. "Dibuka toko baru di 3 tempat, Kemang, Papaya Bandung, Aeon Tangerang" [online] https://twitter.com/DaisoJapan_ID?lang=en [accesed 8 June 2016].

Daiso Japan on Twitter. 2016. "Opened new stores in 3 places, Kemang, Papaya Bandung, Aeon Tangerang” [online] https://twitter.com/ DaisoJapan_ID? Lang $=$ en [accessed 8 June 2016].

Daiso. 2016. "About Daiso" [online] www.daiso.web.id/About/Index/1 [accessed 8 June 2016].

Daiso. 2016. "About" [online] http://www.daiso.web.id/About/Index/3., [accessed 8 June 2016].

Jepang.net. 2017. "Budaya Orang Jepang Membungkuk" [online] http://www.jepang. net/2011/10/budaya-orang-jepang-membungkuk.html [accessed 10 April 2017].

Ono, Shiori. 2017. “An Introduction to Japan's 100 Yen Store Culture” [online] https://build.export.gov/build/groups/public/@bg_jp/documents/webcontent/ bg jp 112234.pdf

Quiz Surprise!! Japan [televised 11 February 2017].

Teresa, Ananda W. 2012. “Daiso Japan Buka Gerai Keenam di Jakarta” [online] http:// bisnis.tempo.co/read/news/2012/11/17/092442318/daiso-japan-buka-geraikeenam-di-jakarta [accessed 14 January 2016]. 
